\title{
GAMBARAN FAKTOR RISIKO INSIDEN KANKER OVARIUM DI RSUD ARIFIN ACHMAD PROVINSI RIAU
}

\author{
Trisia Agusweni ${ }^{1}$, Yulia Irvani Dewi ${ }^{2}$ Erwin $^{3}$ \\ ${ }^{1,2,3}$ Fakultas Keperawatan Universitas Riau Jalan Pattimura No 9 Gedung G Pekanbaru Riau \\ Kode Pos 28131 Indonesia \\ Email: aguswenitrisia3@gmail.com
}

\begin{abstract}
Abstrak
Kanker ovarium dikenal sebagai silent killer karena pada stadium awal penyakit ini tidak menunjukkan gejala klinis yang spesifik. Penyebab kanker ovarium belum diketahui secara pasti akan tetapi berbagai faktor risiko diduga memiliki pengaruh terhadap timbulnya kanker ini. Penelitian ini bertujuan untuk mengetahui gambaran faktor resiko terhadap insiden kanker ovarium di RSUD Arifin Achmad Provinsi Riau. Penelitian menggunakan desain penelitian deskriptif analitik dan pendekatan retrospektif. Sampel penelitian 88 responden (rekam medik) yang diambil berdasarkan kriteria inklusi menggunakan teknik purposive sampling. Analisis yang digunakan adalah analisis univariat untuk mengetahui gambaran distribusi frekuensi. Hasil penelitian menunjukkan dari 88 responden sebanyak 63 responden $(71,6 \%)$ tidak memiliki riwayat keluarga dengan kanker, stadium IIIC sebanyak 62 responden $(70,5 \%)$, usia menarche 5-12 tahun sebanyak 70 responden $(79,5 \%), 36$ responden $(40,9 \%)$ primipara, dan sebanyak 66 responden $(75 \%)$ tidak ada riwayat memakai alat kontrasepsi, menggunakan alat kontrasepsi pil sebanyak 8 responden $(9,1 \%)$ yang lama pemakaian alat kontrasepsi selama 1 tahun sebanyak 7 responden $(8 \%)$ dan 88 responden $(100 \%)$ tidak mengkonsumsi obat subur. Berdasarkan hasil penelitian dapat disimpulkan gambaran usia menarche 5-12 tahun, diharapkan kepada orang yang memiliki faktor resiko kanker ovarium untuk melakukan deteksi dini sebagai upaya pencegahan terhadap kanker ovarium.
\end{abstract}

Kata kunci: Faktor risiko, Kanker ovarium, Reproduksi

\begin{abstract}
Ovarian cancer is known as the silent killer because in the early stages this disease does not show specific clinical symptoms. The cause of ovarian cancer is not known with certainty but various risk factors are thought to influence on the incidence of this cancer. This study aims to describe the risk factors for the incidence of ovarian cancer in Arifin Achmad Hospital, Riau Province. The study used a descriptive-analytic research design and a retrospective approach. The research sample was 88 respondents (medical records) taken based on inclusion criteria using a purposive sampling technique. The analysis was used univariate analysis to describe the frequency distribution. The results showed that 63 respondents (71.6\%) did not have a family history of cancer, IIIC stage as many as 62 respondents (70.5\%), 5-12 years menarche age as many as 70 respondents (79.5\%), 36 respondents (40.9\%) primipara, and as many as 66 respondents (75\%) had no history of using contraception, using pill contraception as many as 8 respondents (9.1\%) who had long use of contraception for 1 year as many as 7 respondents (8\%) and 88 respondents (100\%) did not consume fertile drugs. Based on the results of the study it is expected that people who have risk factors for ovarian cancer to make early detection as an effort to prevent ovarian cancer.
\end{abstract}

Keywords: Risk factors, ovarian cancer, reproduction

\section{PENDAHULUAN}

Salah satu masalah kesehatan reproduksi yang menjadi perhatian yaitu kanker. Kanker merupakan salah satu penyebab kematian di dunia. Menurut
International Agency for Research on Cancer (2018) ditemukan sebanyak 18,6 juta kasus baru dengan kanker dan 9,6 juta orang meninggal. Insiden kanker di Indonesia. terus meningkat setiap tahun. Pada tahun 2013 
Trisia Agusweni, Yulia Irvani Dewi, Erwin, Gambaran Faktor Risiko Insiden Kanker Ovarium di RSUD Arifin Achmad Provinsi Riau

tercatat sebanyak $1,4 \%$ dan meningkat menjadi 1,8\% pada tahun 2018 (Depkes, 2018).

Menurut data dari Global Burden of Cancer insiden kanker reproduksi dengan prevalensi tinggi adalah kanker payudara dengan kasus baru mencapai $24,2 \%$ dan $15 \%$ kematian, kanker serviks 6,6\% kasus baru dan 7,5\% kematian, dan untuk kasus baru kanker ovarium mencapai 4,4\% dan meninggal juga mencapai 4,4\% (IARC, 2018).

Data Word Cancer Research Found International (2018) insiden baru kanker ovarium mengalami peningkatan mencapai 300.000. Indonesia merupakan negara dengan jumlah penderita kanker ovarium yang tertinggi, ditemukan sebanyak 13.310 (7,1\%) kasus baru dan angka kematian akibat penyakit ini mencapai $7.842 \quad(4,4 \%)$ (International Agency For Research On Cancer, 2018).

Kanker ovarium merupakan penyakit yang mematikan pada perempuan, dikarenakan tidak ada cara yang pasti untuk mencegah atau mengetahui jenis kanker ini lebih awal (Buys et al., 2011). Kanker ovarium merupakan penyakit yang ditakuti karena tidak jarang penderitanya berujung pada kematian, karena kanker ovarium dikenal sebagai penyakit yang tumbuh diamdiam namun mematikan (silent killer), karena pada stadium awal penyakit ini tidak menunjukkan gejala klinis yang spesifik
(International Agency for Research on Cancer, 2018).

Kanker ovarium banyak ditemukan pada usia di atas 40 tahun, semakin tinggi usia maka makin tinggi pula kasus yang ditemukan (Prawirohardjo, 2010). Penelitian Johari dan Siregar (2013) menjelaskan bahwa insidensi kanker ovarium banyak ditemukan pada kelompok umur 35-50 tahun (42.1\%). Berdasarkan penelitian yang dilakukan Dhitayoni (2017) di RSUP Sanglah Denpasar Bali bahwa insiden kanker ovarium mengalami peningkatan seiring dengan bertambahnya umur, puncak insiden kanker ovarium terbanyak pada umur 40 - 50 tahun.

Bodelon et al. (2013) menyatakan bahwa wanita dengan primipara memiliki risiko rendah kanker ovarium dibanding dengan nulipara. Berdasarkan studi populasi yang dilakukan di Denmark terhadap 885 perempuan yang didiagnosis Ovarian Serous Borderline Tumor (OSBT) sejak tahun 19922002 memperlihatkan hubungan yang kuat antara paritas dan risiko perkembangan ovarian serous borderline tumor (Rasmussen et al., 2017).

Kanker ovarium berisiko tinggi pada orang yang mempunyai riwayat anggota keluarganya menderita kanker payudara, kanker ovarium, kanker prostat atau kanker rahim (Saydam, 2012). Penelitian Wentzensen (2016) menyatakan bahawa penggunaan kontrasepsi oral juga mempengaruhi risiko faktor kejadian kanker 
ovarium. Durasi penggunaan kontrasepi yang lama berhubungan terhadap penurunan faktor risiko kanker ovarium. Penggunaan kontrasepsi lebih dari 10 tahun memiliki $45 \%$ faktor risiko yang lebih rendah jika dibandingkan dengan penggunaan kurang dari 1 tahun (Tsilidis, K., et al., 2011). Faktor risiko kanker ovarium lainnya adalah usia menarche, pada penelitian Johari dan Siregar (2011) mendapatkan hasil angka yang tinggi pada kelompok usia menarche 5-12 tahun, yaitu 176 orang dengan persentase 52,2\%. Penelitian Yanti dan Sulistianingsih (2015) menjelaskan bahwa usia menarche dini mempunyai risiko 3,6 kali untuk mengalami kanker ovarium.

\section{METODE PENELITIAN}

Penelitian dilakukan di RSUD Arifin Achmad Provinsi Riau. Penelitian ini menggunakan kuantitatif dengan rancangan deskriptif analitik dan pendekatan retrospektif yaitu pendekatan yang digunakan untuk meneliti peristiwa yang sudah berlangsung (Notoatmodjo, 2012).

\section{HASIL PENELITIAN}

\section{A. Analisa Univariat}

\section{Karakteristik Responden}

Tabel 1

Gambaran distribusi frekuensi responden menurut umur, suku, status pernikahan, pekerjaan, dan pendidikan terakhir

\begin{tabular}{|c|c|c|c|}
\hline \multirow[t]{2}{*}{ No. } & Karakteristik Responden & Frekuensi & Persentase \\
\hline & & $\mathbf{n}$ & $(\%)$ \\
\hline \multirow[t]{3}{*}{1} & Kategori Umur & & \\
\hline & a. $\begin{array}{l}\text { Dewasa awal } \\
\text { tahun) }\end{array}$ & 25 & 28,4 \\
\hline & $\begin{array}{l}\text { b. Dewasa menengah (41- } \\
60 \text { tahun) }\end{array}$ & 51 & 58 \\
\hline
\end{tabular}


Trisia Agusweni, Yulia Irvani Dewi, Erwin, Gambaran Faktor Risiko Insiden Kanker Ovarium di RSUD Arifin Achmad Provinsi Riau

\begin{tabular}{|c|c|c|c|}
\hline \multirow[t]{3}{*}{ No. } & Karakteristik Responden & Frekuensi & Persentase \\
\hline & & $\mathbf{n}$ & $(\%)$ \\
\hline & c. Lansia (> 60 tahun) & 12 & 13,6 \\
\hline \multirow[t]{5}{*}{2} & Suku & & \\
\hline & a. Melayu & 68 & 77,3 \\
\hline & b. Minang & 6 & 6,8 \\
\hline & c. Jawa & 4 & 4,5 \\
\hline & d. Batak & 10 & 11,4 \\
\hline \multirow[t]{3}{*}{3} & Status Pernikahan & & \\
\hline & a. Menikah & 77 & 87,5 \\
\hline & b. Belum Menikah & 11 & 12,5 \\
\hline \multirow[t]{7}{*}{4} & Pekerjaan & & \\
\hline & a. Pegawai Swasta & 4 & 4,5 \\
\hline & b. Wiraswasta & 1 & 1,1 \\
\hline & c. PNS & 2 & 2,3 \\
\hline & d. Ibu rumah tangga & 69 & 78,4 \\
\hline & e. Pelajar & 6 & 6,8 \\
\hline & f. Lain-lain & 6 & 6,8 \\
\hline \multirow[t]{6}{*}{5} & Pendidikan & & \\
\hline & a. Tidak tamat SD & 8 & 9,1 \\
\hline & b. SD & 26 & 29,5 \\
\hline & c. SMP & 20 & 22,7 \\
\hline & d. SMA & 24 & 27,3 \\
\hline & e. Perguruan tinggi & 10 & 11,4 \\
\hline \multirow[t]{4}{*}{6} & Riwayat keluarga dengan kanker & & \\
\hline & a. Ada & 25 & 28,4 \\
\hline & b. Tidak ada & 63 & 71,6 \\
\hline & Total & 88 & 100 \\
\hline
\end{tabular}

Tabel 1 menunjukkan dari 88 responden, karakteristik umur responden terbanyak adalah dewasa menengah (41-60 tahun) dengan jumlah 51 responden $(58 \%)$, mayoritas responden dengan suku Melayu berjumlah 68 responden $(77,3 \%)$, sudah menikah dengan jumlah 77 responden $(87,5 \%)$, sebagian besar pekerjaan responden

\section{Gambaran stadium kanker ovarium}

Tabel 2

Distribusi frekuensi responden berdasarkan stadium kanker ovarium

\begin{tabular}{cccc}
\hline No. & Stadium & Frekuensi & Persentase \\
\cline { 3 - 4 } & & $\mathbf{n}$ & $(\boldsymbol{\%})$ \\
\hline 1. & Stadium I & & 1,1 \\
& a. IA & 1 & 9,1 \\
& b. IB & 8 & 1,1 \\
\hline
\end{tabular}




\begin{tabular}{|c|c|c|c|}
\hline \multirow[t]{2}{*}{ No. } & \multirow[t]{2}{*}{ Stadium } & Frekuensi & \multirow{2}{*}{$\frac{\text { Persentase }}{(\%)}$} \\
\hline & & $\mathbf{n}$ & \\
\hline \multirow[t]{4}{*}{2.} & Stadium II & & \\
\hline & a. IIA & 1 & 1,1 \\
\hline & b. IIB & 7 & 8 \\
\hline & c. IIC & 1 & 1,1 \\
\hline \multirow[t]{4}{*}{3.} & Stadium III & & \\
\hline & a. IIIA & 1 & 1,1 \\
\hline & b. IIIB & 2 & 2,3 \\
\hline & c. IIIC & 62 & 70,5 \\
\hline \multirow[t]{2}{*}{4.} & Stadium IV & 5 & 5,7 \\
\hline & Tot & 88 & 100 \\
\hline
\end{tabular}

mayoritas responden menderita kanker

\section{Gambaran usia menarche}

Tabel 3

Distribusi frekuensi responden berdasarkan usia menarche

\begin{tabular}{|c|c|c|c|}
\hline \multirow[t]{2}{*}{ No. } & \multirow[t]{2}{*}{ Usia Menarche } & Frekuensi & Persentase \\
\hline & & $\mathbf{n}$ & $(\%)$ \\
\hline 1. & $5-12$ tahun & 70 & 79,5 \\
\hline 2. & 13-20 tahun & 18 & 20,5 \\
\hline \multicolumn{2}{|r|}{ Total } & 88 & 100 \\
\hline
\end{tabular}

\section{Gambaran paritas}

Tabel 4

Distribusi frekuensi responden berdasarkan paritas

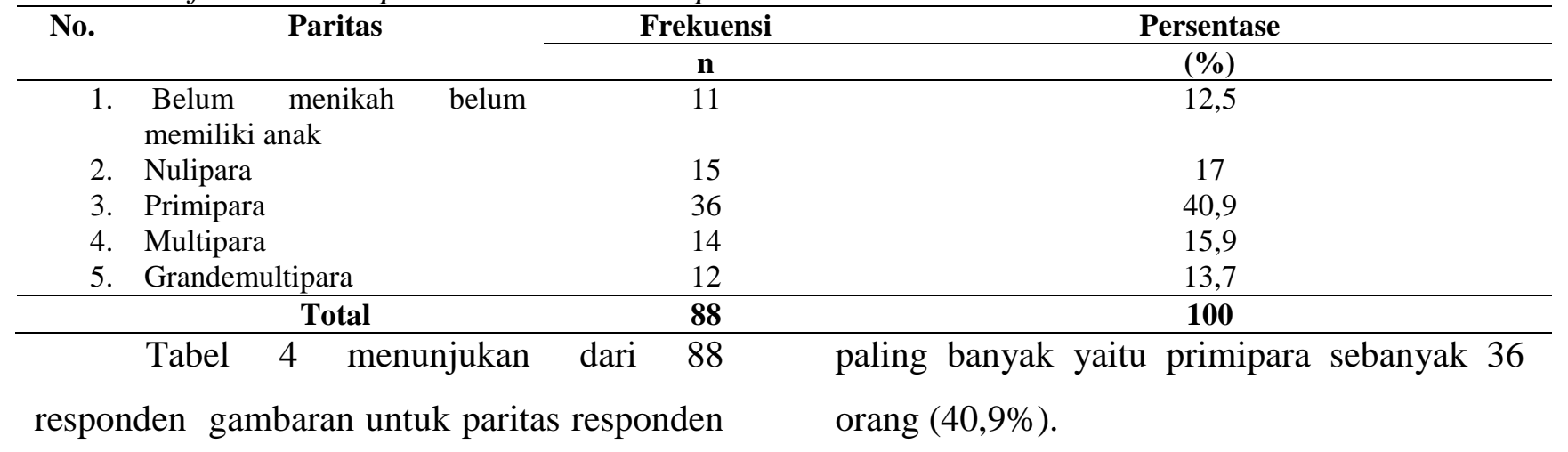


Trisia Agusweni, Yulia Irvani Dewi, Erwin, Gambaran Faktor Risiko Insiden Kanker Ovarium di RSUD Arifin Achmad Provinsi Riau

\section{Gambaran riwayat pemakaian alat kontrasepsi, jenis alat kontrasepsi dan lama pemakaian alat kontrasepsi}

Tabel 5

Distribusi frekuensi riwayat pemakaian alat kontrasepsi, jenis alat kontrasepsi dan lama pemakaian alat kontrasepsi

\begin{tabular}{clcc}
\hline \multirow{2}{*}{ No. } & \multicolumn{1}{c}{$\begin{array}{c}\text { Riwayat Pemakaian } \\
\text { Kontrasepsi }\end{array}$} & Frekuensi & Persentase \\
\cline { 3 - 4 } & $\mathbf{n}$ & $\mathbf{( \% )}$ \\
\hline Riwayat pemakaian alat kontrasepsi & & 12,5 \\
1. & Ya & 11 & 75 \\
2. & Tidak & 66 & 12,5 \\
$3 . \quad$ Belum menikah dan tidak & 11 & \\
\hline
\end{tabular}

Jenis alat kontrasepsi

1. IUD

2. Pil Kontrasepsi

3. Implant

4. Suntik

5. Kondom

1

6. Menikah tidak menggunakan alat kontrasepsi

7. Belum menikah dan tidak menggunakan alat kontrasepsi

89,1

$0 \quad 0$

1

1

$66 \quad 75$

$11-12,5$

Riwayat lama pemakaian alat kontrasepsi

$\begin{array}{lll}\text { 1. Tidak memakai alat kontrasepsi } & 77 & 87,5\end{array}$

2. 1 tahun $\quad 7 \quad 8$

3. 2 tahun $\quad 2 \quad 2,3$

4. 3 tahun $2,2,3$

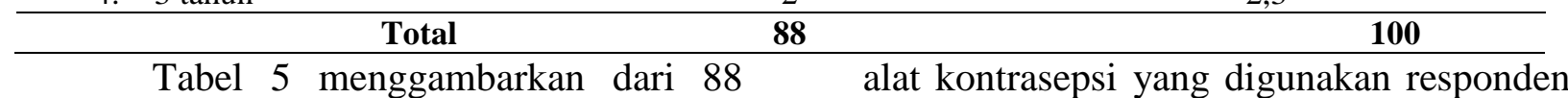

responden didapatkan hasil untuk riwayat adalah pil ssebanyak 8 orang $(9,1 \%)$ dan penggunaan alat kontrasepsi mayoritas lama pemakaian alat kontrasepsi sebagian tidak menggunakan alat kontrasepsi besar adalah 1 tahun sebanyak 7 orang sebanyak 66 orang (75\%). Jenis riwayat $(8 \%)$.

\section{Gambaran pemakaian obat kesuburan}

Tabel 6

Distribusi frekuensi responden berdasarkan pemakaian obat kesuburan

\begin{tabular}{|c|c|c|c|}
\hline \multirow[t]{2}{*}{ No. } & \multirow{2}{*}{$\begin{array}{c}\text { Pemakaian Obat } \\
\text { Subur }\end{array}$} & Frekuensi & Persentase \\
\hline & & $\mathbf{n}$ & $(\%)$ \\
\hline 1. & Memakai & 0 & 0 \\
\hline 2. & Tidak memakai & 88 & 100 \\
\hline & Total & 88 & 100 \\
\hline
\end{tabular}

Tabel 6 menggambarkan semua

responden 88 orang $(100 \%)$ tidak

mengkonsumsi obat kesuburan. 


\section{PEMBAHASAN}

\section{A. Pembahasan Penelitian}

\section{Karakteristik Responden}

a. Umur

Hasil penelitian diperoleh mayoritas usia responden berada pada rentang usia dewasa menengah yaitu 41-60 tahun sebanyak 50 orang $(56,8 \%)$. Hurlock (1980) dalam Farahdika (2015) menyatakan bahwa dewasa menengah merupakan massa transisi dari dewasa awal, pada masa dewasa menengah seseorang mengalami banyak perubahan baik dari segi fisik maupun kesehatan. Dhitayoni (2017) menyatakan bahwa kasus kanker ovarium mengalami peningkatan seiring bertambahnya umur seseorang hal ini dikarenakan faktor degeneratif yaitu keadaan dimana fungsi tubuh seseorang menurun yang terjadi pada usia $>45$ tahun.

Hasil penelitian ini menemukan penderita kanker ovarium berusia (18-40 tahun) sebanyak 25 orang $(28,4 \%)$, pada usia terendah 18 tahun sebanyak 1 orang dan juga belum menikah. Kanker ovarium yang terjadi pada usia 18 tahun akan berdampak pada aspek kehidupan seperti terjadinya kecemasan dan gangguan pada sistem reproduksi seseorang. Hal ini didukung oleh penelitian Smart (2010) yang menyatakan wanita yang menderita kanker pada usia produktif menyebabkan gangguan kualitas hidup secara fisik, kejiwaan, dan kesehatan seksual.
Peneliti berasumsi meskipun insiden terbanyak ditemukan pada dewasa menengah, namun juga ditemukan pada dewasa awal dan juga lansia. Semakin cepat dideteksi secara dini kanker ovarium maka proses pengobatan akan lebih awal dilakukan, sehingga tingkat kesembuhan akan lebih cepat. Hal ini terjadi karena pada usia dewasa muda masih memiliki tingkat kesehatan yang lebih baik, sedangkan pada dewasa menegah dan lansia tingkat kesehatan telah dipengaruhi oleh degenaratif. Hal ini sejalan dengan pendapat Aziz, Andrijono dan Saifuddi (2010) yang menyatakan wanita usia muda yang terkena kanker akan lebih cepat terdiagnosa dalam stadium dini jika dibandingkan dengan pada wanita yang lebih tua. Juga terapi pada wanita muda lebih agresif dari pada terapi untuk wanita yang lebih tua

\section{b. Suku}

Hasil penelitian didapatkan sebagian besar responden bersuku Melayu yang berjumlah 68 orang $(77,3 \%)$. Berdasarkan data Badan Pusat Statistik tahun 2010 mayoritas masyarakat Provinsi Riau bersuku Melayu yaitu 1.828.815 jiwa. Hal ini sejalan dengan penelitian Azizah, Sofian, dan Suyanto (2014) yang menyatakan banyaknya responden yang suku Melayu dikarenakan keadaaan demografi suku di Riau yang mayoritas bersuku Melayu. 
Penelitian Azizah, Sofian, dan Suyanto (2014) yang menyatakan bahwa latar belakang budaya dan suku seseorang mengajarkan bagaimana cara sehat, cara mengenali sakit, dan cara merawat orang sakit, dan efek penyakit yang impresrasinya berbeda menurut kultur masing-masing suku. Nurvinanda Mulatsih, Hartini, dan Nurjannah (2019) menyatakan seseorang dengan latar belakang suku Melayu memiliki tindakan yang cukup baik untuk menghadapi masalah kesehatan dengan cara menentukan dan memilih strategi yang efektif untuk menghadapi dan menyelesaikan bagaimana menghadapi dan merawat seseorang.

\section{c. Status pernikahan}

Hasil penelitian mayoritas responden sudah menikah sebanyak 77 responden (87,5\%). Menurut $\mathrm{BKKBN}$ (2017) rata-rata penduduk Indonesia sudah menikah pada usia >20 tahun. Menurut asumsi peneliti banyaknya responden yang menderita kanker ovarium yang berstatus sudah menikah didukung oleh umur para responden yang berusia 40-50 tahun, yang biasanya sudah menikah. Hal ini didukung oleh penelitian yang dilakukan oleh Ningsih, Pramono dan Nurdiati (2017) yang menyatakan bahwa 78,10\%. penderita kanker telah menikah.

Sampai saat ini tidak diketahui hubungan status pernikahan baik yang sudah menikah ataupun yang belum menikah, tetapi kejadian kanker pada orang yang sudah menikah berkembang dikarenakan keterlambatan melakukan deteksi dini (Berraho, 2012). Hal ini berbeda dengan dengan hasil penelitian yang dimana terdapat responden yang belum menikah sebanyak 11 orang (12,5\%). Dapat disimpulkan bahwa gambaran kanker ovarium terjadi pada pasien yang sudah menikah.

\section{d. Pekerjaan}

Hasil penelitian menggambarkan bahwa mayoritas pekerjaan responden adalah ibu rumah tangga yaitu 69 responden (78,4\%). Menurut asumsi peneliti pekerjaan sangat mempengaruhi kesehatan seseorang dimana perkerjaan sebagai ibu rumah tangga membuat seseorang jarang mendapatkan informasi mengenai kanker ovarium yang menyebabkan banyak para responden yang tidak mengetahui secara detail apa itu kanker ovarium, mengapa bisa terjadi dan apa saja penyebabnya.

Hal ini didukung oleh Pangemanan dan Nelwa (2012) bahwa pekerjaan responden menunjukan bahwa paling banyak responden bekerja sebagai ibu rumah tangga (IRT). Dimana peran sebagai IRT tanpa pekerjaan di luar rumah tentu mendukung aktivitas untuk melaksanakan kegiatan-kegiatan rutin dirumah seperti memelihara dan mempertahankan 
kebersihan dan kenyamanan di dalam rumah tempat tinggal. Dalam hal tersebut peranan IRT sangat penting di dalam keluarga, sebab hampir setiap masalah kesehatan dari awal hingga penyelesaian akan dipengaruhi oleh keluarga. Menurut asumsi peneliti akibat kesibukan bekerja dan juga jenis pekerjaan dapat mempengaruhi seseorang dalam melakukan manajemen perawatan diri. Kesibukan seseorang dengan pekerjaan di dalam rumah mengakibatkan kurangnya interaksi dengan orang lain membuat seseorang minim informasi mengenai kesehatan.

\section{e. Pendidikan}

Hasil penelitian didapatkan sebagian besar pendidikan terakhir responden adalah SD berjumlah 26 orang $(29,5 \%)$. Penelitian Romadani (2014), menyatakan bahwa tingkat pendidikan yang rendah akan berdampak pada pengetahuan yang kurang tentang penyakit, sehingga menyebabkan ketidaktahuan dan keterlambatan deteksi dini terhadap kanker.

Notoatmodjo (2010) menyatakan bahwa pendidikan adalah suatu cara untuk mengembangkan kepribadian dan kemampuan didalam dan diluar sekolah dan berlangsung seumur hidup. Pendidikan dapat mempengaruhi proses belajar, semakin tinggi pendidikan seseorang maka semakin mudah orang tersebut untuk menerima dan mengelola informasi. Asumsi peneliti bahwa tingkat pendidikan akan mempengaruhi bagaimana cara berpikir, bersikap, dan bertindak pada seseorang. Semakin rendah pendidikan seseorang semakin sulit pula kemampuan seseorang untuk menerima edukasi dan informasi mengenai tindakantindakan untuk mencegah terjadinya kanker tersebut.

\section{f. Stadium kanker ovarium}

Hasil penelitian diperoleh bahwa mayoritas responden menderita kanker ovarium stadium IIIC sebanyak 62 orang (70,5\%). Penelitian Dhitayoni (2017) menemukan hal yang sama responden kanker ovarium mayoritas pada stadium IIIC sebanyak 37 orang $(50,68 \%)$. Hal ini didukung oleh penelitian Gajjar, et al (2012) yang menyatakan bahwa kanker ovarium sangat sulit untuk dideteksi secara dini sehingga banyak responden yang datang ke rumah sakit sudah ada pada stadium III-IV. Stadium kanker terdiri dari stadium IA-IV, semakin tinggi stadium kanker maka sel-sel kanker akan metastase ke organ organ lainnya. Hal ini didukung oleh Prawirohardjo (2010) menyatakan kanker ovarium bisa menyebar ke bagian lain, panggul, dan perut melalui sistem getah bening dan melalui sistem pembuluh darah menyebar ke hati dan paru-paru. Berdasarkan hasil penelitian didapatkan bahwa sebagian besar responden menderita 
kanker stadium IIIC. Stadium IIIC menurut Rasjidi, Muljadi, dan Cahyono (2010) dimana pada stadium tersebut sel kanker sudah metastasis intraperitoneal $>2 \mathrm{~cm}$ dan adanya keterlibatan KGB (Kelenjar Getah Bening) retroperitoneal atau ingual.

Menurut asumsi peneliti banyaknya responden yang menderita kanker ovarium stadium IIIC karena kanker sangat sulit mendeteksi secara dini kanker ovarium dan juga tidak adanya penyebab yang pasti mengapa kanker ovarium bisa terjadi sehingga banyak responden dinyatakan menderita kanker stadium III - IV dimana keadaan ini sel-sel kanker sudah metastase ke organ-organ lainya hal ini sama dengan penelitian Gajjar (2012).

\section{g. Riwayat keluarga dengan kanker}

Hasil penelitian menggambarkan bahwa mayoritas responden tidak memiliki riwayat keluarga dengan kanker sebanyak 63 orang $(71,6 \%)$, hanya 25 orang $(28,4 \%)$ yang memiliki riwayat keluarga dengan kanker. Ariani (2015) menyatakan bahwa riwayat keluarga merupakan faktor penting dalam mengidentifikasi apakah seorang perempuan memiliki risiko terkena kanker ovarium. Hal ini didukung oleh Rasjidi (2009) yang menyakatakan bajwa seorang wanita memiliki risiko $7 \%$ terkena kanker ovarium apabila memiliki keluarga dengan riwayat kanker.

Berbeda dengan hasil penelitian yang didapatkan, sebagian besar responden tidak memiliki riwayat keluarga dengan kanker. Menurut asumsi peneliti seseorang yang mengalami kanker ovarium belum tentu memiliki riwayat keluarga dengan kanker. Hal ini didukung oleh penelitian Yanti dan Sulitianingsih (2016) yang menyatakan tidak ada keterkaitkan riwayat keluarga kanker dengan insiden kanker ovarium, karena berdasarkan penelitian yang dilakukan didapatkan hasil 46 dari 70 responden menderita kanker ovarium tetatpi tidak memiliki riwayat keluarga dengan kanker.

\section{h. Usia menarche}

Hal ini dapat mempengaruhi intensitas nyeri pembengkakan payudara yang dirasakan ibu menyusui. Hasil penelitian menggambarkan terbanyak responden mengalami menarche pada usia 5-12 tahun yang berjumlah 70 orang (79,5\%). Usia 5-12 tahun termasuk pada menarche dini dimana kondisi ini termasuk pada pubertas prekok dimana seorang wanita sudah mengalami menarche kurang dari usia 12 tahun (Karapanou dan Papadimitriou, 2010). Penelitian Yanti (2018) menyatakan bahwa responden yang memiliki usia menarche $<12$ tahun memiliki risiko lebih besar terkena kanker ovarium. Semakin banyak jumlah siklus menstruasi yang dilewati maka semakin tinggi pula risiko terkena kanker ovarium. Selain itu, usia menarche dini dikaitkan dengan teori gonadrotopin, dimana hormon 
tersebut penting selama dan pra pubertas, dimana hormone LH berfungsi mematangkan ovarium dan memicu ovulasi serta sintesis dan sekresi estrogen dan progesteron pada wanita sehingga pubertas pada wanita sangat dipengaruhi oleh hormon ini.

\section{i. Paritas}

Hasil penelitian yang dilakukan didapatkan hasil bahwa sebagian besar primipara sebanyak 37 orang (43\%). Penelitian Schuler, Ponnath, Engel dan Ortman (2013) menyatakan ibu dengan primipara memiliki risiko $40 \%$ lebih tinggi mengalami kanker ovarium dan ibu dengan grandemultipara memiliki risiko $80 \%$ lebih rendah untuk mengalami kanker ovarium. Pada penelitian ini, ditemukan sebanyak $14,7 \%$ penderita kanker ovarium dengan grandemultipara. Ada sebanyak $17 \%$ dengan nullipara dan $12,5 \%$ belum menikah dan belum memiliki anak. Berdasarkan asumsi peneliti, bahwa kanker kanker ovarium terjadi pada semua orang baik yang sudah memiliki anak maupun yang belum memiliki anak.

Hal ini kemungkinan erat kaitannya dengan teori Incessant Ovulation yang menyebutkan bahwa pada saat terjadinya ovulasi akan terjadi kerusakan pada epitel ovarium. Untuk proses perbaikan kerusakan ini diperlukan waktu tertentu. Kerusakan epitel yang berkali-kali terutama jika sebelum penyembuhan sempurna tercapai, atau dengan kata lain masa istirahat sel tidak adekuat,maka proses perbaikan tersebut akan mengalami gangguan sehingga dapat terjadi transformasi menjadi sel-sel neoplastik sehingga dengan sering terjadinya kehamilan membuat berkurangnya jumlah ovulasi akan menurunkan paparan ovarium terhadap kemungkinan mutasi gen akibat perbaikan sel epitel setelah ovulasi yang terus menerus (Prawirohardjo, 2010)

\section{j. Riwayat pemakaian alat kontrasepsi}

Hasil penelitian menjelaskan bahwa mayoritas responden tidak memakai alat kontrasepsi sebanyak 66 orang $(75 \%)$ dan hanya 11 orang $(12,5 \%)$ yang menggunakan alat kontrasepsi. Jenis alat kontrasepsi terbanyak yang digunakan responden adalah pil sebanyak 9 orang (10,2\%), dan lama penggunaan alat kontrasepsi pada sebagian besar responden 1 tahun yang berjumlah 7 orang (8\%).

Kontrasepsi merupakan alat untuk mencegah terjadinya kehamilan dengan menggunakan bahan baku preparat estrogen dan progesteron, beberapa jenis kontrasepsi dengan metode hormonal yaitu suntik, pil, dan implan (Harnawatiaj, 2008). Hal ini berbeda dengan Nissa, Widjajanegara, dan Purbaningsih (2017) menyatakan bahwa penggunaan kontrasepsi hormonal berisiko 2,99 kali lebih besar terkena kanker dibandingkan dengan yang tidak menggunakan kontrasepsi hormonal, 
penggunaan kontrasepsi hormonal dapat meningkatkan risiko kanker yang berhubungan dengan faktor hormonal.

Urban et al (2012) menyatakan bahwa tidak terjadi perbedaan yang signifikan antara wanita yang tidak pernah menggunakan alat kontrasepsi dan mereka yang telah menggunakan alat kontrasepsi sehingga pemakaian alat kontrasepsi tidak memiliki pengaruh yang signifikan terhadap penurunan risiko kanker ovarium. Hal ini berlawanan dengan pernyataan dari Ariani (2015) yang menyatakan bahwa penggunakaan alat kontrasepsi bisa mengurangi risiko kanker

Setiati (2009) menyatakan penggunaan pil kontrasepsi bisa menurunkan $40 \%$ risiko kanker ovarium. Menurut Ariani (2017) penggunaan kontrasepsi jenis pil dan lama pemakaian $>5$ tahun bisa menurunkan risiko terkena kanker ovarium mencapai $40 \%$. Tsidilis et al (2011) menyatakan pemakaian alat kontrasepsi yang kurang dari $<5$ tahun dapat meningkatkan risiko kanker ovarium. Menurut asumsi peneliti pemakaian alat kontrasepsi yang sebentar dapat meningkatkan risiko kanker ovarium. Hal ini di dukung oleh penelitian Vessey et al (2013) yang menyatakan bahwa durasi penggunaan alat kontrasepsi yang lebih lama dapat mengurangi risiko terjadinya kanker ovarium.

\section{k.Konsumsi obat kesuburan}

Hasil penelitian didapatkan semua pasien $(100 \%)$ tidak menggunakan obat penyubur. Prawirorahardjo menyatakan obat-obatan yang digunakan untuk meningkatkan kesuburan seperti klomifen sitrat, yang diberikan secara oral dan obat-obatan gonadrotropin yang diberikan dengan suntikan seperti FSH dengan ( $\mathrm{H}$ akan menginduksi terjadinya ovulasi sehingga berisiko tinggi terjadinya kanker ovarium. Laura et al (2013) yang menyatakan bahwa menggunaan obat untuk pengobatan infertilitas dan dalam reproduksi yang dibantu menimbulkan kekhawatiran tentang kemungkinan efek jangka panjang pada perkembangan kanker ovarium epitelial.

Kurta (2012) menyatakan bahwa pemakaian obat penyubur tidak terlalu signifikan untuk mempengaruhi insiden kanker ovarium terdapat $57,7 \%$ responden tidak menggunakan obat kesuburan. Hal ini sejalan dengan penelitian yang mayoritas responden tidak menggunakan obat kesuburan.

\section{SIMPULAN}

Hasil penelitian dapat disimpulkan bahwas gambaran faktor risiko insiden kanker ovarium di RSUD Arifin Achmad disimpulkan bahwa mayoritas reponden berada pada rentang umur dewasa menengah (41-60 tahun), sebagain besar bersuku, mayoritas responden 
sudah menikah, sebagian besar responden bekerja sebagai IRT dan sebagian besar responden memiliki pendidikan SD. Pada umumnya responden menderita kanker ovarium stadium III C, mayoritas responden tidak memiliki riwayat keluarga dengan kanker, sebagian besar responden mengalami menarche pada usia (5-12 tahun, mayoritas responden memiliki 1 anak atau primipara ,sebagian besar responden tidak memakai alat kontrasepsi, mayoritas responden menikah dan tidak menggunakan alat koontrasepsi, dan seluruh responden tidak memakai obat kesuburan. Kesimpulan gambaran Ca Ovarium banyak terjadi pada responden yang mengalami menarche di usia 5-12 tahun hal ini sama dengan penelitian Penelitian Fahlevy (2010) dan Yanti (2018) menyatakan bahwa responden yang memiliki usia menarche <12 tahun memiliki risiko lebih besar terkena kanker ovarium.

\section{SARAN}

Hasil penelitian ini di harapkan menjadi salah satu referensi bagi ilmu keperawatan khususnya keperawatan maternitas mengenai gambaran faktor risiko insiden kanker ovarium.dan juga diharapkan dapat memberikan informasi kepada masyarakat untuk meningkatkan kesadaran masyarakat mengenai faktor risiko kanker ovarium sehingga dapat menentukan langkahlangkah pencegahan dan deteksi dini mengenai kanker.

\section{DAFTAR PUSTAKA}

Ariani, S. (2015). Stop kanker. Yogyakarta: Istana Media

Aziz, M.F., Adrijono., \& Saifuddin, A. B. (2010). Buku acuan nasional onkologi ginekologi. Jakarta: Bina Pustaka Sarwono Prawirohardjo.

Azizah, A., Sofian, A., \& Suyanto, S. (2014). Gambaran kualitas hidup pasien kanker serviks yang menjalani radioerapi di rsud arifin achmad provinsi riau periode 2011 - 2013. Diperoleh tanggal 19 Mei 2019 dari https://www.neliti.com/publications

Badan Kependudukan dan Keluarga Berencana. (2017). Usia pernikahan ideal 21-25 tahun. Diakses tanggal 21 Mei 2019 dari https://www.bkkbn.go.id Berraho, et al. (2012). Sociodemographic factors and delay in the diagnosis of cervical cancer in Morocco. Diperoleh tanggal 24 Mei 2019 dari https://www.ncbi.nlm.nih.gov/pmc/arti cles

Bodelon., et al. (2013). Hormonal risk factors and invasive epithelial ovarian cancer risk by parity. Diperoleh tanggal 18 Februari 2019 dari https://www.nature.com/articles/

Bray, F., et al. (2018). Global cancer statistics 2018: GLOBOCAN estimates of incidence and mortality worldwide for 36 cancers in 185 countries. CA. Diperoleh tanggal 3 Februari 2019 dari https://onlinelibrary.wiley.com

Buys, S. S., et al. (2011). Effect of screening on ovarian cancer mortality: the Prostate, Lung, Colorectal and Ovarian (PLCO) cancer screening randomized controlled trial. Diperoleh 12 Maret 2019 dari https://jamanetwork.com/journals

Departemen Kesehatan RI. (2018). Potret sehat Indoneisa dari riskesdas 2018. Jakarta: Depekes RI. Diperoleh pada 25 
Trisia Agusweni, Yulia Irvani Dewi, Erwin, Gambaran Faktor Risiko Insiden Kanker Ovarium di RSUD Arifin Achmad Provinsi Riau

Januari $2019 \quad$ dari http://www.depkes.go.id

Dhitayoni, I. A., \& Budiana, I. N. G. (2017). Profil pasien kanker ovarium di Rumah Sakit Umum Pusat Sanglah DenpasarBali Periode Juli 2013-Juni 2014. Diperoleh tanggal 20 Januari 2019 dari https://simdos.unud.ac.id

Farahdika, A., \& Azam, M. (2015). Faktor risiko yang berhubungan dengan penyakit jantung koroner pada usia dewasa madya (41-60 tahun). Diperoleh tanggal 20 Januari 2019 dari https://journal.unnes.ac.id/sju/index.ph p/ujph/article

Gajjar, K., Ogden, G., Mujahid, M. I., \& Razvi, K. (2012). Symptoms and risk factors of ovarian cancer: a survey in primary care. Diperoleh tanggal 23 Mei 2019 dari https://www.ncbi.nlm.nih.gov/pmc

International Agency for Research on Cancer. (2018). Latest global cancer data: cancer burden rises to 18.1 million new cases and 9.6 million cancer deaths in 2018. Diperoleh tanggal 24 Januari 2019 dari https://www.iarc.fr

Johari, A. B., \& Siregar, F. G. (2013). Insidensi kanker ovarium berdasarkan faktor risiko di RSUP Haji Adam Malik Tahun 2008-2011. Diperoleh tanggal 30 Januari 2019 dari https://jurnal.usu.ac.id

Karapanou, O., \& Papadimitriou, A. (2010).

Determinants of menarche. Reproductive Biology and Endocrinology. Diperoleh 4 Juni 2019 dari

https://rbej.biomedcentral.com/articles

Kurta, et al. (2012). Use of fertility drugs and risk of ovarian cancer. Diperoleh tanggal 10 Juni 2019 dari http://cebp.aacrjournals.org/content
Laura, et al. (2013). Oral contraceptive pills as primary prevention for ovarian cancer. Diperoleh tanggal 27 Mei 2019 dari https://www.ncbi.nlm.nih.gov

Ningsih.D.P.S., Pramono.D., \& Nurdiati. D. (2017). Faktor-faktor yang berhubungan dengan kejadian kanker serviks di rumah sakit Sardjito Yogyakarta. Diperoleh tanggal 23 Mei 2019 dari https://media.neliti.com/media/publicat ions

Nurvinanda, R., Mulatsih, S., Hartini, S., \& Nurjannah, I. (2019). Dukungan keluarga dalam merawat anak dengan thalassemia beta mayor. Diperoleh tanggal 20 Mei 2019 dari http://jurnalilmiah.stikescitradelima.ac id

Notoatmodjo, S. (2010). Ilmu perilaku kesehatan Jakarta. Rineka Cipta.

Notoatmodjo, S. (2010). Metodologi penelitian kesehatan. Jakarta. Rineka Cipta.

Pangemanan. J., \& Nelwan. J. (2012). Perilaku masyarakat tentang program pemberantasan penyakit dbd di kabupaten minahasa utara. Diperoleh tanggal 24 Mei 2019 dari https://ejournal.unsrat.ac.id/index.php

Prawirohardjo, S. (2010). Buku acuan nasional pelayanan kesehatan maternal dan neonatal. Jakarta : PT Bina Pustaka Sarwono Prawirohardjo.

Rasjidi, I. (2009). Deteksi dini dan pencegahan kanker pada wanita. Jakarta: Sagung Seto

Rasjidi,I., Muljadi,R., Cahyono,K. (2010). Imaging ginekologi onkologi. Jakarta: Sagung Seto

Rasmussen, E., et al. (2017). Parity, infertility, oral contraceptives, and hormone replacement therapy and the risk of ovarian serous borderline tumors. 
Diperoleh 5 Februari 2019 dari https://www.sciencedirect.com

Romadani, D. I. (2014). Efektifitas promosi kesehatan sebagai deteksi dini kanker serviks untuk menurunkan angka kematian. Diperoleh 19 maret 2019 dari https://jurnal.unimus.ac.id/index

Saydam. (2012). Waspadai penyakit reproduksi anda. Bandung: Reka Cipta.

Setiadi. 2013. Konsep dan praktik penulisan riset keperawatan. Yogyakarta: Graha Ilmu

Setiati, A. (2009). Waspadai 4 kanker ganas pembunuh wanita. Yogyakarta: Andi

Smart, A. (2010). Kanker organ reproduksi. Yogyakarta: A+ Plus Book.

Schuler. S., Ponnath. M., Engel.J., \& Ortman.O. (2013). Ovarian epithelial tumors and reproductive factors: $a$ systematic review. Diperoleh tanggal $30 \quad$ Mei $2019 \quad$ dari https://www.ncbi.nlm.nih.gov

Tsilidis, K., et al. (2011). Oral contraceptive use and reproductive factors and risk of ovarian cancer in the European Prospective Investigation into Cancer and Nutrition. Diperoleh 15 Februari 2019 dari https://www.ncbi.nlm.nih.gov

Urban, et al. (2012). Injectable and oral contraceptive use and cancers of the breast, cervix, ovary, and endometrium in black south african women: case-control study. Diperoleh tanggal 26 Mei 2019 dari https://www.ncbi.nlm.nih.gov/pubmed

Vessey. M., \& Yeates. D. (2013). Oral contraceptive use and cancer: final report from the oxford-family planning association contraceptive study. Diperoleh tanggal 28 Mei 2019 dari https://www.ncbi.nlm.nih.gov

Wentzensen, N., et al. (2016). Ovarian cancer risk factors by histologic subtype: an analysis from the ovarian cancer cohort consortium. Diperoleh 17 Maret 2019 dari

https://www.ncbi.nlm.nih.gov/pmc/artic les

Word Cancer Research Fund. (2018). Ovarian Cancer Statisctics diperoleh tanggal 20 Mei 2019 dari https://www.wcrf.org/dietandcancer

Yanti, D. A. M, \& Sulistianingsih,A. (2015). Faktor determinan kanker ovarium di rumah sakit umum daerah abdoel moelok provinsi Lampung 2015. Diperoleh tanggal 20 Februari 2019 dari http://ejournal.umm.ac

Yulianti, I. S., (2014). Gambaran dukungan sosial keluarga dan kualitas hidup lansia dengan hipertensi di Puskesmas Citangkil Kota Cilegon. Diperoleh tanggal 21 Mei 2019 dari http://repository.uinjkt.ac.id/dspace 